\title{
KEBAHASAAN SINEMATIK BERNUANSA PLURALITAS DALAM IKLAN BNI TAPLUS ANAK
}

\author{
Rustono Farady Marta, Patricia Robin \\ rmarta@bundamulia.ac.id, probin@bundamulia.ac.id \\ Universitas Bunda Mulia
}

\begin{abstract}
Early education introduces children to how to manage money, especially since growing up to become a person who values money more. Related to this, PT. Bank Negara Indonesia, Tbk (BNI) released the BNI Taplus Anak program for children aged 0 to 17 years. To proclaim the service, advertisements were made that were very close to the reality of the lives of parents and children. This advertisement tells a group of bands with the name "Kancil" which consists of 5 people with high plurality nuances where they have different ethnicity, or skin color but live in harmony in order to realize the dream of becoming a band that follows the competition. The problem of this research lies in the meaning of the sign of the cinematic linguistic pattern of the BNI Taplus Anak version of the Kancil Band. This study aims to determine the mapping of storytelling patterns in the BNI ad, then identify the categorical of each of the cinematic lines and reveal the meaning of the sign. This study takes the qualitative study of Christian Metz's Cinema Semiology which seeks to build a model of the film linguistic system as text, which is found in sintagma as a structured group of signs. Research findings show that implicit meanings of plurality order are forward and have Systematic flow is not only based on the image of the product as a supporter of the value of its production, but moral responsibility in presenting story ideas is successfully presented to the audience. The filmmaker who creates the creative idea of making this advertisement succeeds in knitting the story in a congruent manner, the pattern of storytelling chronologically traced at a level where the scope of the framework is smaller implies a similar and consistent meaning in the form of plurality.
\end{abstract}

Keywords: BNI Taplus Anak Ads, Cinematic Language, Metz's Semiology, Plurality

\begin{abstract}
ABSTRAK
Pendidikan dini mengenalkan anak cara mengelola uang sangat dibutuhkan agar si kecil tumbuh menjadi pribadi yang lebih menghargai uang. Terkait hal tersebut, PT. Bank Negara Indonesia, Tbk (BNI) merilis program BNI Taplus Anak bagi anak usia 0 sampai dengan 17 tahun. Untuk memproklamirkan layanan tersebut, dibuatlah iklan yang sangat dekat dengan realita hidup orang tua dan anak. Iklan ini menceritakan sekelompok band dengan nama "Kancil" yang beranggotakan 5 orang dengan nuansa pluralitas tinggi dimana mereka memiliki perbedaan suku, ataupun warna kulit tetapi tetap menjadi satu mewujudkan impian menjadi Band yang mengikuti perlombaan. Permasalahan penelitian ini terletak pada makna tanda pola kebahasaan sinematik iklan BNI Taplus Anak Versi Band Kancil. Penelitian ini bertujuan untuk mengetahui pemetaan pola penceritaan dalam iklan BNI tersebut, kemudian mengidentifikasi kategorial masing-masing alur sinematiknya dan mengungkap makna tandanya. Penelitian ini mengambil kajian kualitatif Semiologi Sinema Christian Metz yang berusaha membangun model dari sistem kebahasaan film sebagai teks, yaitu terdapat pada sintagma sebagai kelompok yang terstruktur dari tanda-tanda.Temuan riset diperoleh bahwa makna secara tersirat yang menampilkan tatanan pluralitas dibahasakan mengalun ke depan serta memiliki alur sistematis tidak hanya berpaku pada imaji produk sebagai penyokong nilai produksinya namun tanggung jawab moral dalam menyajikan ide cerita berhasil terpaparkan kepada khalayak penonton. Sineas yang menciptakan ide kreatif pembuatan iklan ini berhasil merajut
\end{abstract}


jalannya cerita secara kongruen, pola bercerita secara kronologis ditelusuri pada tingkatan yang lebih kecil lingkup kerangkanya menyiratkan makna yang serupa dan konsisten berupa pluralitas.

Kata kunci: Iklan BNI Taplus Anak, Kebahasaan Sinematik, Semiologi Metz, Pluralitas

\section{PENDAHULUAN}

\section{Pentingnya kebiasaan}

menabung untuk masa depan dapat berimplikasi pada dampak positif ke berbagai sektor (Ulfi, dkk, 2017:13). Uang tabungan adalah simpanan yang bisa digunakan sewaktu-waktu saat genting atau saat muncul kebutuhan tidak terduga. Tanpa sadar, kebiasaan menabung juga bisa membentuk kepribadian, Lail dan Maulana (2015:54) menyebutkan bahwa kegiatan ini termasuk sarana untuk menanamkan nilai-nilai positif terhadap keluarga terutama anakanak. Pendidikan sedini mungkin untuk mengenalkan anak cara mengelola keuangan yang baik sangat dibutuhkan agar si kecil akan tumbuh menjadi pribadi yang lebih menghargai uang.

Beberapa cara yang bisa dilakukan oleh orang tua untuk membantu anak menabung adalah dengan mengenalkan konsep uang, misalnya dalam kehidupan nyata, dimana anak diberikan kesempatan untuk berbelanja dan menghitung sendiri pengeluaran dan uang kembalian yang ia terima. Cara kedua sangat erat dengan ketegasan orang tua. Anak diberikan uang saku yang tepat dan sesuai, dimana bila si anak ingin membeli barang lain di luar uang tersebut, si anak diwajibkan untuk menabung. Celengan menjadi cara yang bisa membuat si anak semakin semangat untuk menabung.

Cara yang paling menarik dan menjadi pilihan masyarakat zaman sekarang adalah dengan menabung di bank. Cara ini terbukti efektif, karena si anak merasakan memiliki tabungan sendiri, dimana ia akan memiliki kartu serta buku tabungan layaknya orang dewasa. Beberapa bank juga menawarkan jasa membuat kartu tersebut dengan tampilan menarik, seperti tokoh kartun ataupun foto anak itu sendiri. Keuntungan dan keinginan memberikan pelayanan kepada anak dan orang tua ini yang menjadi dasar bagi PT. Bank Negara Indonesia, Tbk (BNI) dalam membuat program BNI Taplus Anak, sebuah program bagi anak usia 0 sampai dengan 17 tahun untuk belajar menabung sejak dini.

"Program terbaru tersebut ditujukan untuk membantu dan memfasilitasi kebutuhan menabung anak sejak usia dini. Mereka akan diberikan buku tabungan dan dicetak dengan nama mereka sendiri dengan melakukan setoran awal sebesar Rp 100.000. Karena dicetak dengan nama mereka sendiri, anak akan merasa 
bangga.

Sebagai

penyeimbang, kami akan mengirimkan notifikasi melalui SMS kepada orang tua agar orang tua bisa memantau dan mengawasi transaksi mereka," jelas Darmadi Sutanto selaku Direktur Consumer \& Ritel Banking BNI yang dikutip SWA, 27 Juli 2011. (Sumber:

https://swa.co.id/swa/listed -articles/ingin-garapnasabah-lifetime-bnitaplus-anak-diluncurkan)

Terdapat pembatasan debit serta penggunaan kartu ATM BNI Taplus Anak, yaitu hanya sampai pada Rp 500.000,- per hari. Adapun persyaratan yang mudah dan manfaat yang besar, BNI Taplus Anak akan menjadi pilihan masyarakat Indonesia masa kini. (Sumber: http://www.bni.co.id/id$\mathrm{id} /$ personal/simpanan/bnitaplusanak)

Merujuk pada program ini, BNI Taplus Anak membuat sebuah iklan yang dekat dengan segmentasi yang dituju, yaitu orang tua dan anakanak. Iklan merupakan salah satu media komunikasi pemasaran yang kerap digunakan dalam upaya memperkenalkan produk kepada konsumen (Natalia dan Mulyana, 2014: 119) sehingga bentuk promosi ini paling dikenal dan banyak dibahas orang. Hal ini tak terlepas dari daya jangkau yang luas. Iklan pun menjadi suatu instrumen promosi yang penting, khususnya bagi perusahaan yang memproduksi barang atau jasa yang ditujukan pada masyarakat luas.

Iklan ini bercerita mengenai sekelompok band yang terdiri dari lima anak tergabung dalam Band "Kancil". Mereka ingin mengikuti sebuah kompetisi yang mengharuskan mengirimkan CD demo sebagai syarat audisi. Terbentur masalah biaya, Band "Kancil" menemukan solusi dengan keberadaan BNI Taplus Anak. Dianggap sebagai sebuah cara yang positif, orang tua dari dua pemeran utama ini pun mengantarkan si anak ke BNI dan membuka tabungan, diikuti oleh tiga temannya yang lain. Singkat cerita, Band ini tidak berhasil lolos audisi, tetapi tabungan yang dimiliki cukup menjadi "modal" membuat Video Klip sendiri.

Iklan BNI Taplus anak ini mengambil tema yang sederhana namun pesan mendalam. Hal ini dibuktikan secara nyata dalam pemilihan talent dan susunan gambar yang terjalin menjadi sebuah cerita. Bukan hanya satu tipe keluarga atau pertemanan yang diangkat, pada iklan tersebut terdapat beberapa karakter utama yang terdiri dari beberapa suku dan karakter. Hal ini ditunjukkan secara jelas dengan warna kulit dan cara bicara satu sama lain yang membawa unsur kesukuannya yang ditampilkan secara konsisten dengan nuansa keberagaman secara dominan. 
Pemetaan pola dan alur cerita menghimpun sebuah pesan utama yang menjadi wadah dari makna yang ada di dalamnya. Hal ini sejalan dengan keberadaan sebuah pesan berupa iklan BNI Taplus Anak yang memiliki makna di dalamnya. Bukan semata dari pemerannya, melainkan dari sisi sinematografi iklan. Fokus masalah yang dibahas dalam penelitian Iklan BNI Taplus Anak Versi Band Kancil ini dimaksudkan untuk mengungkap makna dari faktor kebahasaan sinematik iklan. Hal ini tidak terlepas dari fakta bahwa terdapat tanda yang mengandung makna dari sisi sinematografi yang sangat dimungkinkan mengandung ideologi di belakangnya. Oleh karena itu, permasalahan penelitian ini adalah makna tanda dari pola kebahasaan sinematik iklan BNI Taplus Anak Versi Band Kancil.

Penelitian ini penting dilakukan untuk memaknai sebuah iklan yang bertujuan mempersuasi khalayak ternyata tidak semata memberikan pesan sebegitu adanya. Dibangun sebuah konstruksi tertentu yang tertuang dalam penyusunan adegan, pemilihan shot, penentuan talent, hingga teknik editing, sehingga menjadi sebuah iklan yang bermakna. Pembahasan ini penting bagi masyarakat dan pemilik iklan karena akan membongkar beragam paparan kepentingan di dalamnya. Selain itu, pemaknaan pola kebahasaan sinematik iklan BNI Taplus Anak Versi Bank Kancil ini juga diharapkan dapat menginspirasi masyarakat Indonesia akan keberagaman suku bangsa dipersatukan dalam suatu sajian sinematik yang menarik. Pada gilirannya fungsi iklan tidak saja berfungsi sebagai media promosi semata karena pemaknaan yang diperoleh mengekstensi pemahaman pada tataran preventif konflik horisontal di masyarakat. Penelitian ini bertujuan untuk mengetahui pemetaan pola penceritaan dalam iklan BNI Taplus Anak Versi Band Kancil, kemudian mengidentifikasi kategorial masing-masing alur sinematik iklan BNI Taplus Anak Versi Band Kancil. Selanjutnya mengungkap makna tanda iklan BNI Taplus Anak Versi Band Kancil.

Penelitian ini diharapkan memberi gambaran kepada peneliti selanjutnya mengenai studi semiotika, juga menjadi bahan bagi pendalaman kajian Ilmu Komunikasi khususnya yang berkaitan dengan studi semiotika terkait makna dari unsur kebahasaan sinema. Hal ini juga berkaitan dengan sinematografi khususnya yang dikemas dalam bentuk iklan komersil. Selain itu, diharapkan mampu menjadi masukan dan evaluasi dalam membuat pesan iklan, terutama dalam kaitannya dengan pembuatan iklan dengan alur kebahasaan sinematik. Pihak BNI pun bisa menggunakan penelitian ini sebagai acuan dalam pembuatan iklan baik yang memiliki konsep serupa atau alur lain yang memiliki makna implisit 
dan eksplisit. Penelitian ini juga diharapkan memberikan gambaran menyeluruh terkait makna iklan yang memberikan kontribusi bagi pihak yang membuat karya serupa, baik dari komunitas film indie ataupun penikmat film. Masyarakat yang menerima terpaan iklan dengan alur sinematik ini juga diharapkan menjadi lebih kritis dan memahami maksud di balik pesan yang disampaikan.

Upaya peneliti dalam mengarahkan penelitian agar sesuai dengan fokus utama, maka disusun dalam bentuk kerangka pemikiran berikut

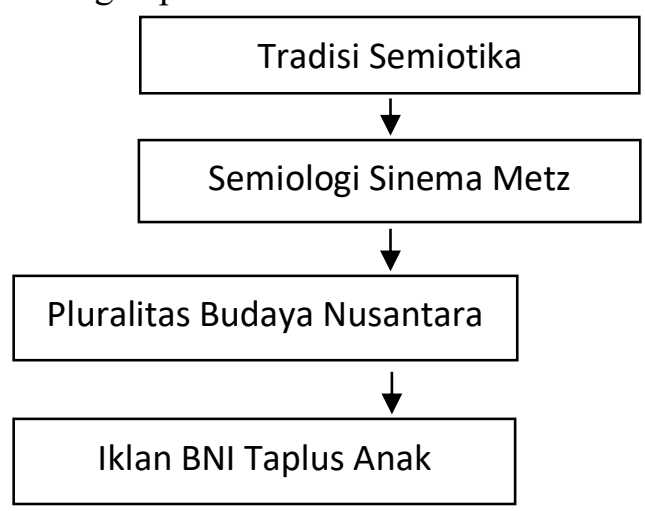

\section{Bagan.1. Kerangka Pemikiran Penelitian}

Tradisi semiotika sebagai salah satu dari tujuh tradisi ilmu komunikasi dipilih peneliti sebagai pijakan utama desain penelitian berupa semiologi sinema Metz, kemudian konsep yang dilibatkan adalah Pluralitas Budaya Nusantara. Hal ini ditempuh peneliti untuk mengungkap makna dari faktor kebahasaan sinematik iklan dalam Iklan BNI Taplus Anak Versi Band Kancil. Pendekatan semiotika terhadap teori komunikasi menunjukkan cara pemahaman kita terhadap proses representasi tanda-tanda melalui benda, ide, keadaan, situasi, perasaan, dan kondisi di luar tanda-tanda itu sendiri.yang dijalankan secara interaktif dalam komunikasi. Tradisi semiotika memiliki tiga ranah dalam teori-teorinya, yaitu pesan, media, dan budaya serta masyarakat. Semiotika berupaya menemukan tanda termasuk hal-hal tersembunyi di balik sebuah tanda, baik berupa teks, iklan, dan berita.

Penelitian ini akan dirunut dengan menggunakan semiologi sinema yang dicetuskan oleh Christian Metz menerapkan gagasan konseptual "language" guna menggambarkan kata dan imaji. Teori ini beranggapan bahwa produk audio visual, baik berbentuk sinema maupun televisi adalah bahasa dan keduanya mengunakan kode-kode (codes) dan tanda-tanda (signs) untuk membentuk struktur kebahasaan (grammar). Menurut Dewi, dkk (2017:21) Metz memandang shot tidak lebih seperti sebuah ungkapan daripada kata, meskipun tidak selalu menyerupai. Makna dalam film tidak secara langsung dijelaskan oleh analogi ikonik, sehingga diperlukan pemahaman membaca film yang mendalam.

Segala bentuk komunikasi pada dasarnya adalah bahasa. Itulah sebabnya teori ini menganggap bahwa sinema bisa dikatakan sebagai sejenis bahasa, namun itu bukanlah sistem bahasa. Seperti yang ditegaskan Metz "it's not because the cinema is a language that it can tell us such fine stories, but rather it has become a language because it has told such fine stories" (Metz, 1991:47)

$$
\text { Menurut Krisna }
$$
gambaran dan suara dalam film memiliki arti denotatif, namun bantuan khas dari 
teknik pengambilan gambar dapat membentuk konotasi sinematik. Film dikategorikan ke dalam langage sebagai bahasa pada tingkatan yang lebih umum, berbeda dengan langue turut mempertimbangkan fonem padanan kesatuan bunyi terkecil dari artikulasi kedua. Semiologi sinema menegaskan bahwa literatur seperti novel dan film mengindikasikan beberapa unsur, seperti meaning (makna), konotasi denotasi, sinkronik diakonik, intertekstualitas, dan kode-kode. Bateman (2007:13) mengacu pada analogi struktur kebahasaan sinematik Metz, terbagi menjadi tujuh pasang oposisi biner untuk memilahmilah kecenderungan sebuah karya audio visual bekerja. Pertama terkait plot alur cerita utama yang terbagi menjadi syntagma dan autonomous shot, kemudian alur syntagma terbagi kembali menjadi chronological dan achronological. Jika merujuk pada achronological, maka terbagi kembali menjadi paralel syntagma dan bracket syntagma. Di sisi lain, bagian chronological terbagi pula menjadi descriptive syntagma atau dikemas narrative untuk dibagi kembali menjadi alternate (narrative) syntagma dan linear narrative. Pada tahapan linear narrative, dirunut pada adegan per adegan (scenes) atau kumpulan beberapa adegan (squences), setelah itu teks siap dianalisis baik episodic dan ordinary. Adapun penjelasan masing-masing komponen tersebut akan disinggung pada hasil dan diskusi.

Kemajemukan dalam sebuah wujud persatuan bangsa merupakan wujud pluralitas di Tanah Air, dimana terdapat keragaman, keunikan, dan parsial. Kondisi ini tidak dapat dipungkiri karena di tanah Nyiur Melambai ini secara antropologis dan historis memperlihatkan realitas bahwa tersaji perbedaan etnis, budaya, dan agama yang saling mengikatkan diri dengan lainnya menjalin suatu ikatan sebagai bagian dari warga bangsa. (Syam, 2011:260)

Hernawan (2017:78) menyebutkan bahwa pondasi dasar yang diperlukan dalam rangka menjaga pluralitas dapat dilihat indikasinya melalui sikap saling mempercayai antara sesama anggota masyarakat yang memiliki latar belakang beragam. Sikap tersebut dalam mewujudkan kerjasama seluruh lapisan dan golongan dari segala aspek kehidupan sosial kemasyarakatan dalam harmonisasi yang baik, sekaligus demi tercapainya tujuan pembangunan nasional.

Secara harafiah kata plural diartikan sebagai jamak atau majemuk, pada perkembangannya kata ini dipelajari dalam wujud paham atau aliran sehingga disebut pluralisme. Salah satu tokoh yang memperoleh julukan sebagai 'Bapak Pluralisme Indonesia' oleh Presiden ketiga Republik Indonesia (RI) Bpk. Dr. Susilo Bambang Yudhoyono adalah K.H. Abdurrahman Wahid atau yang akrab dipanggil 'Gus Dur'. Presiden keempat Republik Indonesia ini senantiasa membangun pola berpikir kebangsaan, dimana terdapat toleransi yang diartikulasi dari sebuah relasi yang bersifat aktif dalam kerangka besar berbangsa. (Suwardiyamsyah, 2017:121) Achmad (2014:189) menyebutkan bahwa sebagian orang memahami pluralisme sama dengan pluralitas, namun terdapat perbedaan yang mendasar antara kedua istilah tersebut. Pluralitas pada 
hakikatnya terbagi menjadi dua definisi, yaitu: bersifat vertikal atau keniscayaan dari Sang Pencipta dan horisontal sebagai kehendak manusia untuk manusia. Kemajemukan dalam kehidupan manusia sebagai suatu kodrati yang patut disyukuri manusia atas rancangan-Nya yang begitu mulia, kemudian keberagaman ini sudah selayaknya disambut dengan sikap toleransi untuk menghargai antar sesama manusia. Dalam kehidupan sosial bermasyarakat di Indonesia, permasalahan pluralitas dan keragaman suku atau etnis tertentu, Agama, Ras, dan Antar golongan (SARA) seringkali menimbulkan konflik horisontal. Hal ini tentu berawal dari ketegangan dalam pola interaksi antar individu maupun kelompok yang didorong oleh ideologi politik, serta kepentingan kekuasaan. Sejarah telah mencatat bahwa perebutan kekuasaan dan pengaruh kepentingan politik antar suku bangsa kerap kali digunakan sebagai komoditas pemecah persatuan nasional. (Suparno, 2004:77)

Pluralitas budaya termasuk di dalamnya berupa entitas masing-masing kearifan daerah harus dipandang sebagai aset Negara Indonesia, dengan tidak menghalangi komunikasi sebagai perekat kesatuan nasional. (Collins, 2014:177) Peran komunikasi sejatinya turut melestarikan pluralitas budaya tersebut melalui berbagai kanal, baik di masingmasing individu, kelompok komunitas, organisasi ataupun korporasi, hingga pada media massa.

Peneliti telah menguraikan dimensi konseptual untuk definisi pluralitas, kemudian menyajikan beberapa tinjauan konstruktivis terhadap multikulturalisme tersebut, sebelum akhirnya mencoba untuk mengaitkan pertimbangan atas bangunan konsep pluralitas itu secara keseluruhan dengan realitas masyarakat Indonesia yang majemuk.

\section{METODE PENELITIAN}

Riset ini bersandar pada paradigma konstruktivisme sosial merupakan pemikiran yang mempersoalkan persepsi individu dalam suatu diskursus, sehingga realitas tidak dipahami dalam lingkup obyektif. (Hanitzsch,2001:224) Metode penelitian yang dipakai dalam penelitian ini menggunakan pendekatan kualitatif. Kualitatif itu sendiri menggunakan multi metode dalam hal fokus penelitian, di mana melibatkan proses interpretasi pada kondisi subyek yang alamiah (Denzin \& Lincoln, 1994).

Unit analisis penelitian ini berupa iklan BNI Taplus Anak yang dipublikasikan secara resmi oleh PT. Bank Negara Indonesia, Tbk pada tanggal 14 Juni 2013, disematkan pada media youtube

https://www.youtube.com/watch?v=yZJ

GhWyvXes\&t=33s bertajuk "Wujudkan Impianmu dengan BNI Taplus Anak". Adapun durasi iklan keseluruhan sepanjang 4 menit 19 detik.

Penelitian ini mengambil kajian kualitatif Semiologi Sinema Christian Metz yang berusaha membangun model dari sistem kebahasaan film sebagai teks, yaitu terdapat pada sintagma sebagai kelompok yang terstruktur dari tandatanda. John Bateman dan Karl Heinrich berargumen dalam bukunya yang berjudul Multimodal Film Analysis: How Film Mean, bahwa metzain grande syntaqmatiq mendapatkan kritik yang besar tapi hanya beberapa yang valid. 
Dalam penelitian ini, ditekankan bahwa terdapat tiga (3) bentuk kritik utama dalam menolong membangun pikiran, yaitu ketangguhan, keterjangkauan dan kegunaan model film.

Pertama, model dari Metz benar benar menekankan pada kebahasaan dari narasi film dan menolak fakta, bahwa pesan dalam film membuat proses pembuatan film menjadi bersamaan, generatif, dan proses waktu nyata berjalan dengan cara yang berjejaring. Pada tahap awal penelitian Metz, dia percaya bahwa tanda-tanda filmik tidak sewenangwenang atau simbolis, namun ikonik. Selanjutnya Ia juga menyadari bahwa kode film tidak naif namun interpretasi saling terkait dengan konvensi dan konteks sosial (Batemen dan Schmidt, 2012).

Kedua, model Metz tidak menunjukkan lapisan abstraksi proses kognitif film diciptakan oleh para sineas. Dalam buku The Analysis of Film, Raymond Bellour (2000) menunjukkan bahwa kemungkinan versi baru tingkatan sintagmatik harus menekankan pada dimensi ini, "Di sisi lain, versi baru dari grande syntagmatique perlu memperkuat tingkat abstraksi secara berurutan. untuk memberi cap secara definitif efek struktural yang merata, atau aplikasi deskriptif antara kode dan teks sehingga memperbaiki kekurangan sebelumnya" (Bellour, 2000:17).

Ketiga, model Metz memberi penekanan pada proses pembuatan makna penonton, diharapkan makna tersebut mampu melampaui kekhususan kelompok orang. Pencipta film atau penerima menyandikan dan menafsirkan makna film berdasarkan pada kesamaan bahwa kita semua memiliki kompetensi penafsiran film, dengan cara yang sama seperti kita memiliki kompetensi linguistik.

Dalam penelitian ini, iklan BNI Taplus Anak Versi Band Kancil menjadi unit analisis. Peneliti mengambil keseluruhan adegan iklan untuk mengetahui pemetaan pola penceritaan, serta mengidentifikasi kategorial masingmasing alur sinematik iklan BNI Taplus Anak Versi Band Kancil, hingga pada akhirnya ditemukan makna di balik iklan tersebut.

\section{HASIL DAN PEMBAHASAN}

Semiologi Metz pada awal penelitian menekankan pada kebahasaan dari narasi film menganggap tanda-tanda filmik tidak sewenang-wenang atau simbolis, namun ikonik. Kode film (dalam hal ini iklan BNI Taplus Anak Episode Band Kancil) tidak naif, namun sarat akan interpretasi yang berkaitan dengan konvensi dan konteks sosial. Penekanan model Metz adalah proses pembuatan makna penonton, yaitu ketika makna tersebut mampu melampaui kekhususan kelompok orang. Baik pencipta film atau penerima pesan mampu menyandikan dan menafsirkan makna film berdasar kesamaan bahwa setiap audience memiliki kompetensi penafsiran film (dalam hal ini iklan BNI Taplus Anak Episode Band Kancil), dengan cara yang sama seperti kepemilikan kompetensi linguistik.

Penelitian terkait konsistensi pluralitas dalam iklan BNI Taplus Anak Versi Band Kancil ini menggunakan sekitar 16 scene untuk dikaji. Adapun pembagian scene tersebut berdasarkan urutan adegan yang mendukung keutuhan 
cerita iklan. Berdasarkan pemetaan pola adegan iklan BNI Taplus Anak, kemudian dikerucutkan menjadi sebelas adegan. Proses reduksi didasarkan pertimbangan prariset peneliti, dimana asumsi peneliti terdapat konstruksi makna pluralitas yang tersirat di balik struktur kebahasaan sinematik pada sebelas adegan iklan tersebut. Scene yang diangkat oleh peneliti dalam Tabel.1 mengenai pemetaan pola adegan iklan akan dibagi kembali ke dalam klasifikasi Metz Grande Syntagmatique yang terdiri dari tujuh tahap dengan pembagian yang mengedepankan pada alur bercerita dari iklan BNI Taplus Anak Episode Band Kancil. Pereduksian ini berkaitan erat dengan kesatuan ideologi yang mengikat di belakangnya. Dalam hal ini, peneliti mengasumsikan pluralitas yang menyadari hakikat adanya keberagaman kultural sebagai unit analisis. Pluralitas pada iklan tersebut menajamkan dugaan peneliti bahwa PT. Bank Negara Indonesia, Tbk mempunyai cara tersendiri dalam mengakomodir perbedaan latar belakang Suku, Ras, Agama, dan Antar-golongan (SARA) selain tujuan iklan komersil yang mempromosikan produknya.

Tabel 1. Pemetaan Pola Adegan Iklan BNI Taplus Anak

\begin{tabular}{|l|l|c|l|}
\hline No. & \multicolumn{1}{|c|}{ Adegan } & \multicolumn{1}{|c|}{ Durasi } & \multicolumn{1}{|c|}{ Setting } \\
\hline S01 & Buku Tabungan dan text BNI Taplus Anak & $0: 00-00: 04$ & - \\
\hline S02 & Pengamen akan bernyanyi dan Perkenalan Band Kancil & $00: 05-00: 58$ & Garasi Rumah Beni \\
\hline S03 & Pengetahuan Band Kancil tentang Kompetisi Musik & $00: 59-01: 11$ & Sekolah Band Kancil \\
\hline S04 & $\begin{array}{l}\text { Beni melihat dan menghubungkan Kompetisi Musik dengan BNI } \\
\text { Taplus Anak }\end{array}$ & $01: 12-01: 21$ & Sekolah Band Kancil \\
\hline S05 & Beni menceritakan kepada Keluarga terkait Kompetisi Musik & $01: 22-01: 29$ & Rumah Beni \\
\hline S06 & $\begin{array}{l}\text { Keluarga menemani membuat BNI Taplus Anak untuk Beni } \\
\text { dibantu oleh Customer Service BNI }\end{array}$ & $01: 30-01: 39$ & Kantor Bank BNI \\
\hline S07 & $\begin{array}{l}\text { Beni, Mutia dan Betty memegang Buku Tabungan BNI Taplus } \\
\text { Anak }\end{array}$ & $01: 40-01: 43$ & Garasi Rumah Beni \\
\hline S08 & Notifikasi SMS tabungan Meilan dan Wajah Ibu bahagia & $01: 44-01: 50$ & Rumah Meilan \\
\hline S09 & Keinginan Tommy untuk belanja tetapi ditahan oleh Betty & $01: 51-01: 59$ & Jalan Raya \\
\hline S10 & Tommy bangga dengan Kartu ATM yang dimiliki & $02: 00-02: 07$ & Garasi Rumah Beni \\
\hline S11 & $\begin{array}{l}\text { Anggota Band Kancil menarik uang dari ATM dan } \\
\text { mengumpulkan uang hasil tabungan }\end{array}$ & $02: 08-02: 36$ & ATM BNI \\
\hline S12 & Pembuatan CD demo rekaman Band Kancil & $02: 37-02: 53$ & Studio Rekaman \\
\hline S13 & $\begin{array}{l}\text { Menunggu waktu pengumuman dan hasil pengumuman Kompetisi } \\
\text { Musik }\end{array}$ & $02: 54-03: 17$ & Garasi Rumah Beni \\
\hline S14 & Pembuatan Video Clip Band Kancil & $03: 22-03: 42$ & Lokasi shooting Video Clip \\
\hline S15 & Ajakan Band Kancil kepada khalayak tujuan untuk menabung & $03: 44-04: 13$ & Lokasi shooting Video Clip \\
\hline S16 & Logo BNI & $04: 14-04: 19$ & - \\
\hline & Sumber: Olahan Peneliti) & $=$ adegan yang direduksi; $=$ adegan \\
\end{tabular}


Pada adegan S02 nampak bahwa seorang pengamen sedang menghampiri sebuah rumah di depan pintu garasinya sembari akan mendendangkan lagunya. Di sisi lain, dari dalam garasi terdengar hingga ke luar suara latihan Band Kancil. Kelompok musik moderen ini memperkenalkan anggotanya masingmasing, yaitu Beni (12 Tahun) sebagai Drummer, Papua bassist Betty (11 Tahun), seorang peranakan Tionghoa bernama Meilan (11 Tahun) di posisi keyboardist, blasteran Indo bernama Tommy (12 Tahun ) bertindak sebagai guitarist, seorang gadis sawo matang yang tidak lain merupakan adik Beni bernama Meutia (10 Tahun) menjadi vokalis band. Nampak adanya perpaduan Bhinneka di antara mereka berlima ditelusuri dari latar belakang berbeda, sehingga alur chronological dari iklan BNI Taplus Anak ini dibuka. Hal ini sejalan dengan penyemaian makna pluralitas yang sebenarnya, Sapendi (2012:167) menyebutkan istilah tersebut tidak berpretensi menghilangkan nilai- nilai partikular. Adapun syntagma yang sedang dialunkan dari produser iklan ini adalah cerita secara singkat mengenai profil tokoh-tokoh utama yang menghiasi jalannya iklan untuk diperkenalkan kepada khalayak penontonnya.

Bukan tanpa sebab dan tujuan mereka berlatih secara regular, karena ada impian terbesit menjadi sebuah band yang dikenal orang banyak dan dihargai karyanya. Cara untuk mendapatkan pengakuan atau terkenal tersebut dipaparkan pada iklan bagian S03 tepatnya dengan setting di sekolah. Tampak sekelompok band berlima menampakkan punggungnya menghadap ke majalah dinding yang memajang poster dan flyer kompetisi musik, tampak kekompakan dari personil dari beda latar belakang budaya Band Kancil. Menurut Hasbullah (2012:38) menyebutkan bahwa kondisi ini merupakan aset untuk memupuk solidaritas sosial, dengan dibekali kesetiakawanan, solidaritas, dan toleransi.

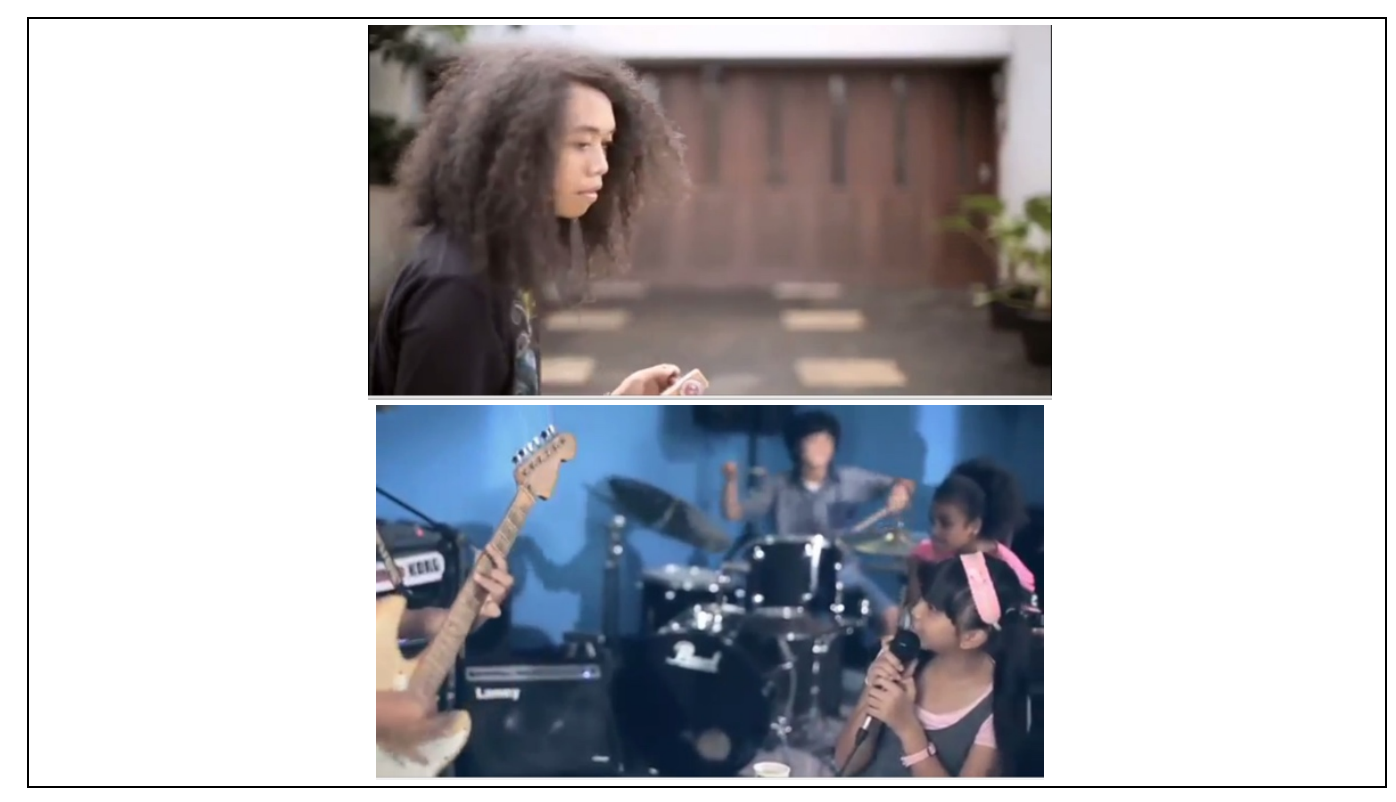

Communication 10, Nomor 1, April 2019 
Gambar 1. Potongan Adegan S02 durasi 00:05-00:58

Sumber: https://www.youtube.com/watch?v=yZJGhWyvXes\&t=33s

Kiranya alur chronological tergambar jelas bila dihubungkan dengan S02 yaitu ketika mereka latihan begitu giat. Melihat poster bersama-sama, perhatian mereka tertuju pada "kesulitan" yang harus mereka hadapi, yaitu tidak adanya dana untuk membuat sebuah CD Demo lagu yang menjadi syarat utama mengikuti kompetisi musik tersebut. Menyajikan poster kompetisi musik secara utuh kemudian membagi dan mendetailkan gambar sampai dengan ke beberapa shot terkait syarat menunjukkan proses sinematik yang diusung adalah bergaya narrative. Setelah pembagian tersebut ternyata ada alur cerita yang sedikit berbelok, yaitu ketika poster yang awalnya menjadi perhatian utama Beni. Selanjutnya justru alur cerita bergeser (alternate) dengan memperlihatkan Beni memilih mengambil Flyer dan membawanya untuk didiskusikan dengan sesama anggota Band Kancil di pinggir lapangan sekolah.

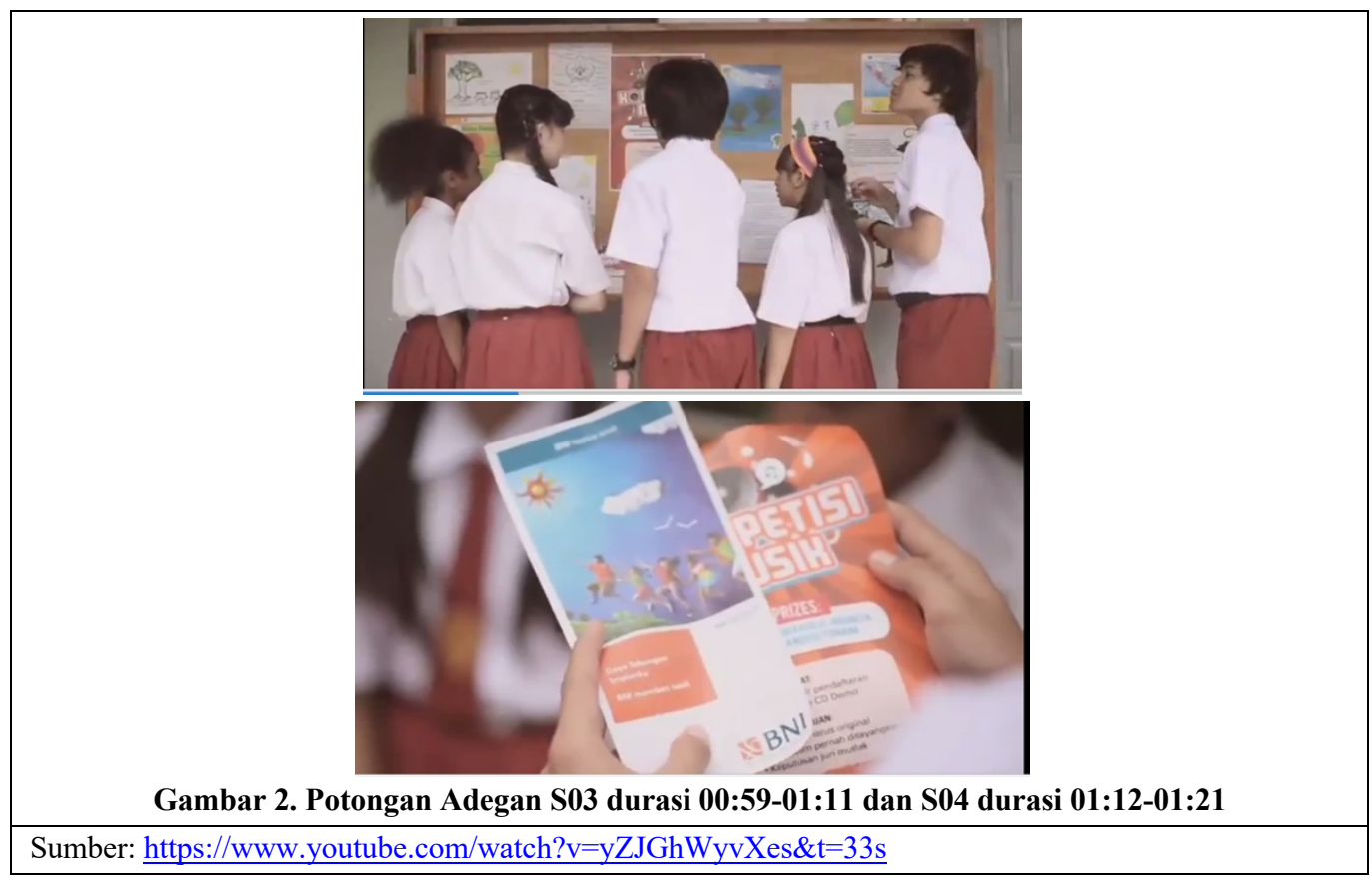

Kekompakan sebagai sebuah band yang ingin terkenal sudah tergambar sejak kisah awal iklan BNI Taplus Anak ini berlanjut dengan alur chronological di S04. Didominasi oleh Beni sebagai leader, ia tidak bersusah payah berpikir sendiri ketika menemui kesulitan mencari dana untuk membuat 
sebuah CD Demo yang digunakan sebagai cara mengikuti kompetisi musik (syntagma). Alur yang berjalan selanjutnya adalah Beni mengambil posisi berdiri untuk berbincang di pinggir lapangan sekolah, sementara temanteman lainnya akan duduk di pinggir lapangan sekolah. Adik Beni, Meutia akan menyingkirkan sebuah flyer yang ternyata adalah flyer BNI Taplus Anak. Beni yang melihat flyer tersebut langsung mengambil dari Meutia dan melihat adanya kesempatan membuat CD Demo dengan bantuan informasi flyer tersebut.

Keberadaan lebih dari satu atau jamak merupakan konsep utama pluralitas yang menunjukkan fakta empiris manusia selaku subyek kebudayaan berupa individu yang berbeda satu sama lainnya. Hawasi (2005:S41) menegaskan mencerminkan tataran definitif yang berbeda dengan multikulturalisme, dimana masyarakat yang multikultural terbiasa dengan interaksi aktif antar budaya plural dalam kehidupan sehari-hari cenderung ada pemahaman akan perbedaan tersebut untuk duduk dalam posisi sejajar. Keberagaman tokoh dalam alur cerita ditampilkan sebagai suatu deskripsi kebhinnekaan, tidak dikemas adanya konflik serta pemahaman akan kesetaraan di antara mereka.

Shot yang digunakan untuk menyandingkan dua flyer BNI Taplus Anak dan flyer Kompetisi Musik begitu detail (narrative), bersambung dengan kebutuhan mereka akan dana pada scene sebelumnya (linear narrative). Potongan demi potongan adegan pun dilakukan pada adegan bertema "bantuan dana untuk CD Demo Kompetisi Musik" (sequences). Mulai dari akan duduk di pinggir lapangan, memegang flyer BNI Taplus Anak disandingkan dengan flyer Kompetisi Musik, dilanjutkan dengan adegan mengejar mobil BNI Taplus Anak yang akan meninggalkan halaman sekolah. Hal ini semakin ideal dan bersambung dengan paparan anggota Band Kancil yang menguatkan pesan bahwa menabung adalah hal penting untuk meraih impian yang disisipkan di akhir iklan (episodic).

Keinginan dikenal masyarakat luas menjadi impian dari Band Kancil. Walaupun tidak dipaparkan secara gamblang, kompetisi musik, menabung pribadi dan mengumpulkan uang secara kolektif menjadi cara untuk mencapai mimpi tersebut. Merujuk pada setiap scene yang sudah dibahas di atas, aspek pluralitas tidak bisa lepas dalam potongan adegan yang disajikan dalam iklan BNI Taplus Anak, termasuk pada S07 dimana Beni, Meutia dan Betty berkumpul di Garasi Rumah Beni untuk saling memperlihatkan buku tabungan yang dimiliki. Sejalan dengan prinsip utama pluralitas yang diuraikan oleh Ropii (2017:14) memperlihatkan perbedaan sebagai ciri khas bangsa Indonesia, dimana karakter budaya yang demikian beragam berpotensi membentuk identitas nasional yang kuat, tangguh dari gangguan dan ancaman disintegrasi bangsa. Selain itu, keberadaan buku tabungan ini menjadi motivasi serta penanda komitmen bersama, terutama bagi anak yang memiliki mimpi, bahwa dengan BNI Taplus Anak, kemandirian dan kedewasaan bisa mengecek sendiri jumlah tabungan akan terwujud. 
Selanjutnya, alur chronological tidak dipungkiri terus berlanjut dalam S07 ini, walaupun pemaparannya tidak detail dan sekedar menggambarkan permukaan saja (descriptive).

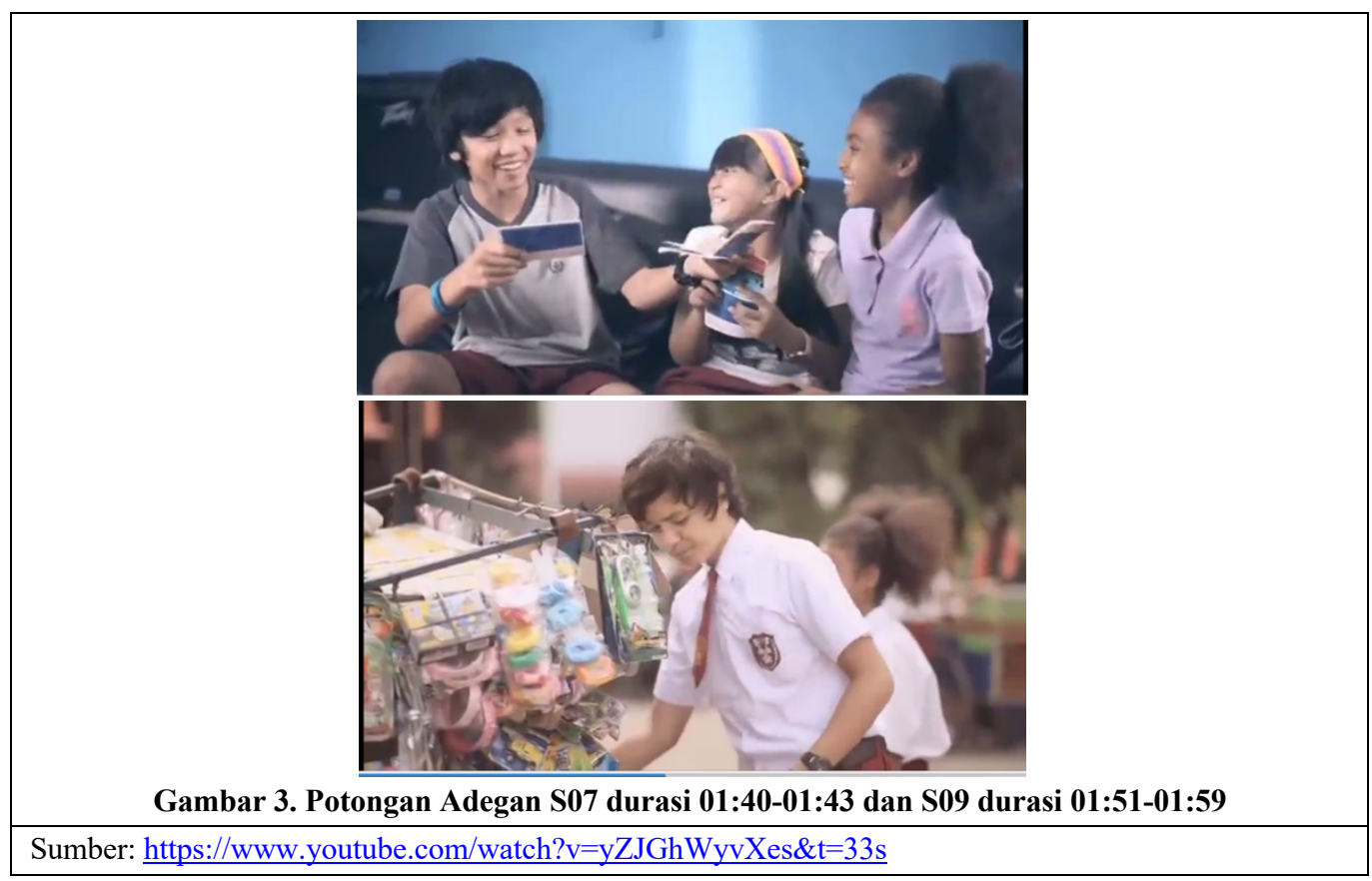

Perjalanan multikultural dari iklan BNI Taplus Anak tidak pernah lepas dari setiap scene yang disajikan. Walaupun tidak lima anggota Band Kancil berkumpul untuk membahas terkait kompetisi, nyatanya sosok Tommy (wajahnya terlihat blasteran atau campuran Indonesia dengan Warga Negara Asing nampak dari ciri fisik yang cenderung lebih tinggi dari teman sebayanya) dan Betty (gadis asal Papua) memiliki kisah tersendiri. Tidak relevan dengan tujuan awal yaitu menjadi terkenal dengan mengikuti kompetisi, gambar Tommy yang tidak jadi membeli jajanan lantaran "diingatkan" oleh Betty untuk menabung sangat erat berkaitan dengan keberadaan Tabungan BNI Taplus Anak. Oleh karena itu, S09 disebut sebagai suatu autonomous shot, yaitu ketika keberadaan scene ini tidak bersambung dengan scene sebelumnya, tetapi tetap digunakan lantaran mempengaruhi esensi dan kepentingan cerita secara keseluruhan. 


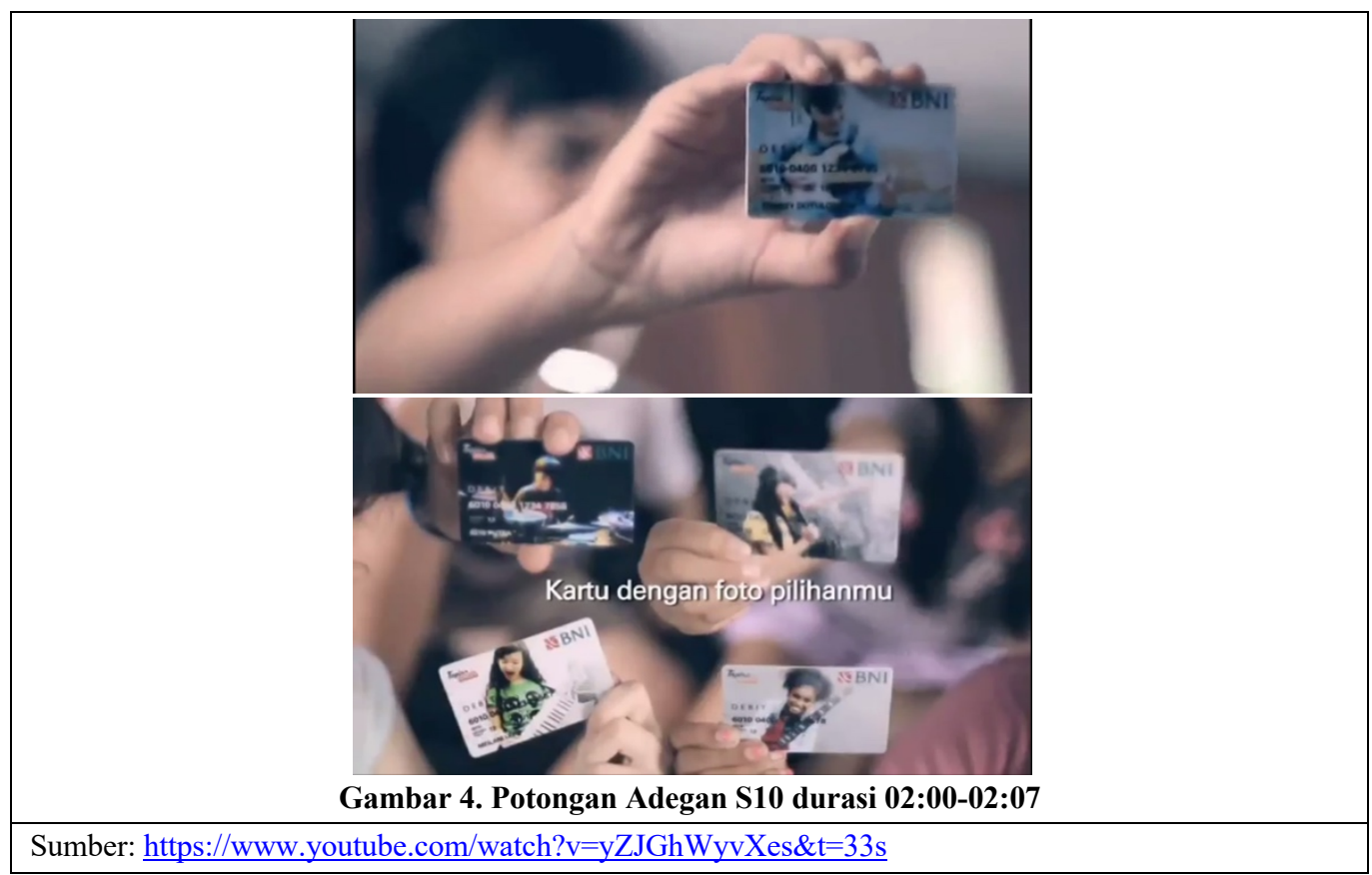

Tommy yang pada S09 menjadi karakter utama yang memilih menabung daripada menghabiskan uangnya untuk jajan di sekolah, kembali menjadi sorotan utama. Bukan karena sosoknya ditonjolkan paling berbeda dibandingkan anggota band lainnya, namun Tommy memiliki kebimbangan dan kisah tersendiri berjuang menyisihkan uangnya untuk menabung. Pada S10, Tommy masuk ke Garasi Rumah Beni, basecamp Band Kancil dengan membawa sebuah kartu ATM dengan wajah dirinya. Syntagmas terasa dalam alur ini lantaran Kartu ATM tersebut menunjukkan kepemilikan akan sebuah tabungan yang uang di dalamnya akan membantu mewujudkan mimpi membuat $\mathrm{CD}$ dan ikut kompetisi. Hal ini juga merupakan kelanjutan dari proses menabung di BNI Taplus Anak (chrological). Kartu ATM tersebut ternyata tidak dimiliki oleh Tommy saja, tetapi oleh seluruh anggota Band Kancil, dengan ukuran atau bentuk yang sama. Hal ini ditunjukkan dengan zoom in shot masing-masing kartu. Gaya narrative dan linear narrative tergambar jelas dalam scene ini lantaran penggambarannya cukup detail serta runut dari scene atau kisah yang sudah ada sebelumnya. Tetapi penjelasan tentang kartu ATM ini tidak dilanjutkan pada bagian adegan selanjutnya, sehingga hanya dianggap sebagai bagian scene (bukan episodic). 


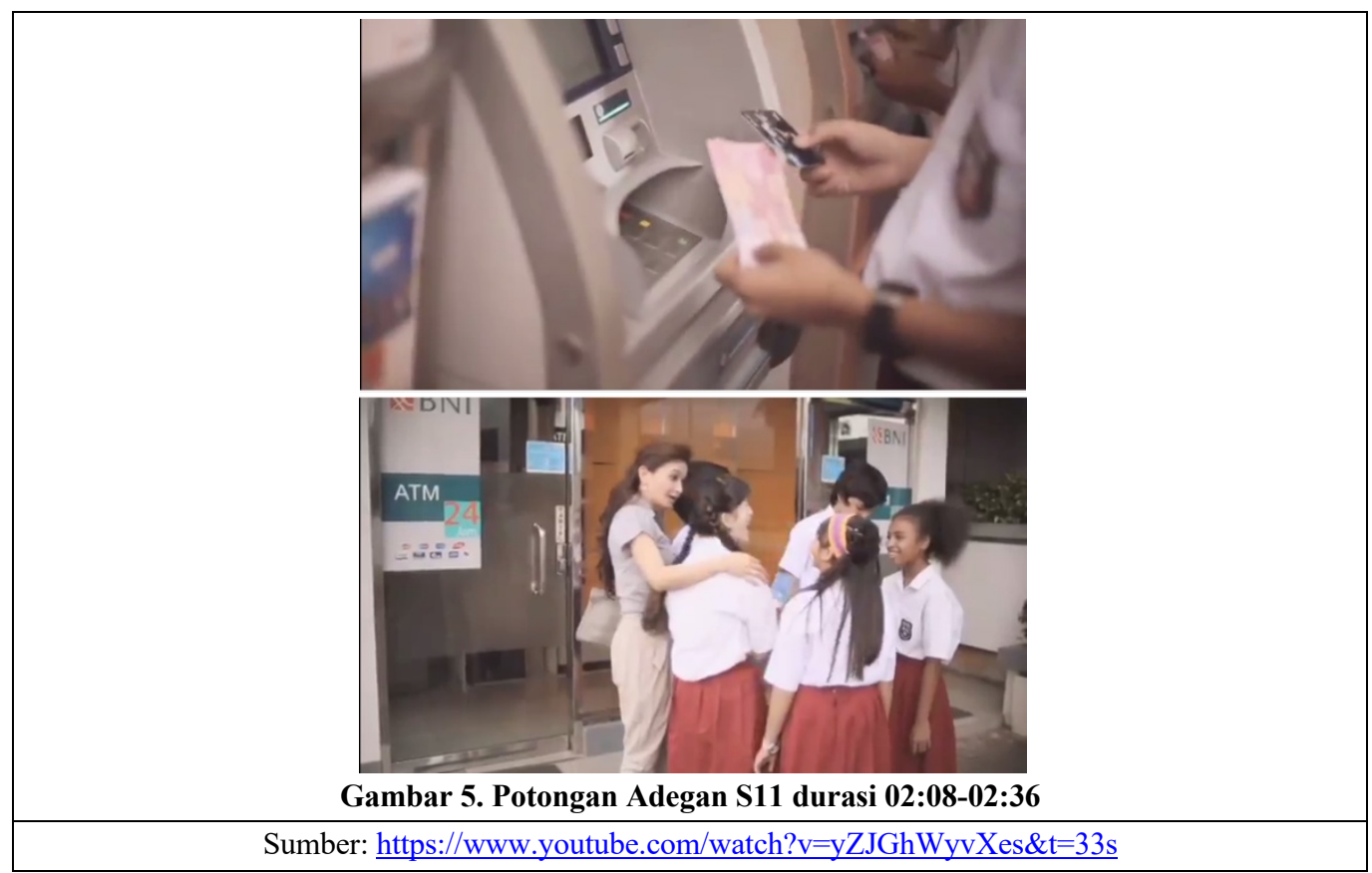

Uang menjadi subjek utama dalam S11. Setelah membuka tabungan di Kantor BNI, memiliki buku tabungan dan kartu ATM sendiri, lima anggota Band Kancil lengkap dengan keragaman warna kulit dan sukunya, melanjutkan kisah dengan mengambil uang dari tabungan masing-masing. Dari scene ini, terlihat bahwa uang terkumpul, otomatis pengisahan yang disusun dari awal bahwa meraih mimpi itu mudah terus terjalin sampai scene ini (syntagmas dan chronological). Dengan cara pengambilan gambar yang spesifik, gaya narrative dan linear narrative terbuki efektif, lantaran yang dipaparkan dalam gambar bukan hanya uangnya saja, melainkan ada cerita di sana, yaitu dari mulai kartu ATM dimasukkan oleh masing-masing anggota Band Kancil ke mesin atm, hingga uang tersebut diambil dan dikumpulkan di tangan Meilan dan Ibunya. Prinsip kepluralitasan serta keheterogenitasan (Astra, 2014:4) menjadi semakin kental lantaran Meilan yang dipercaya menjadi pengumpul uang, walaupun secara suku, ras dan warna kulit, ia yang paling berbeda di antara anggota lainnya. Bukan berdiri sendiri, memiliki lokasi yang sama, nyatanya potongan adegan demi adegan terjadi dalam S11 ini (sequences). Walaupun adegan demi adegan ini berdiri sendiri, gaya episodic tetap terbukti lantaran apa yang menjadi kajian utama dari scene ini dibahas di akhir iklan BNI Taplus Anak (episodic). 


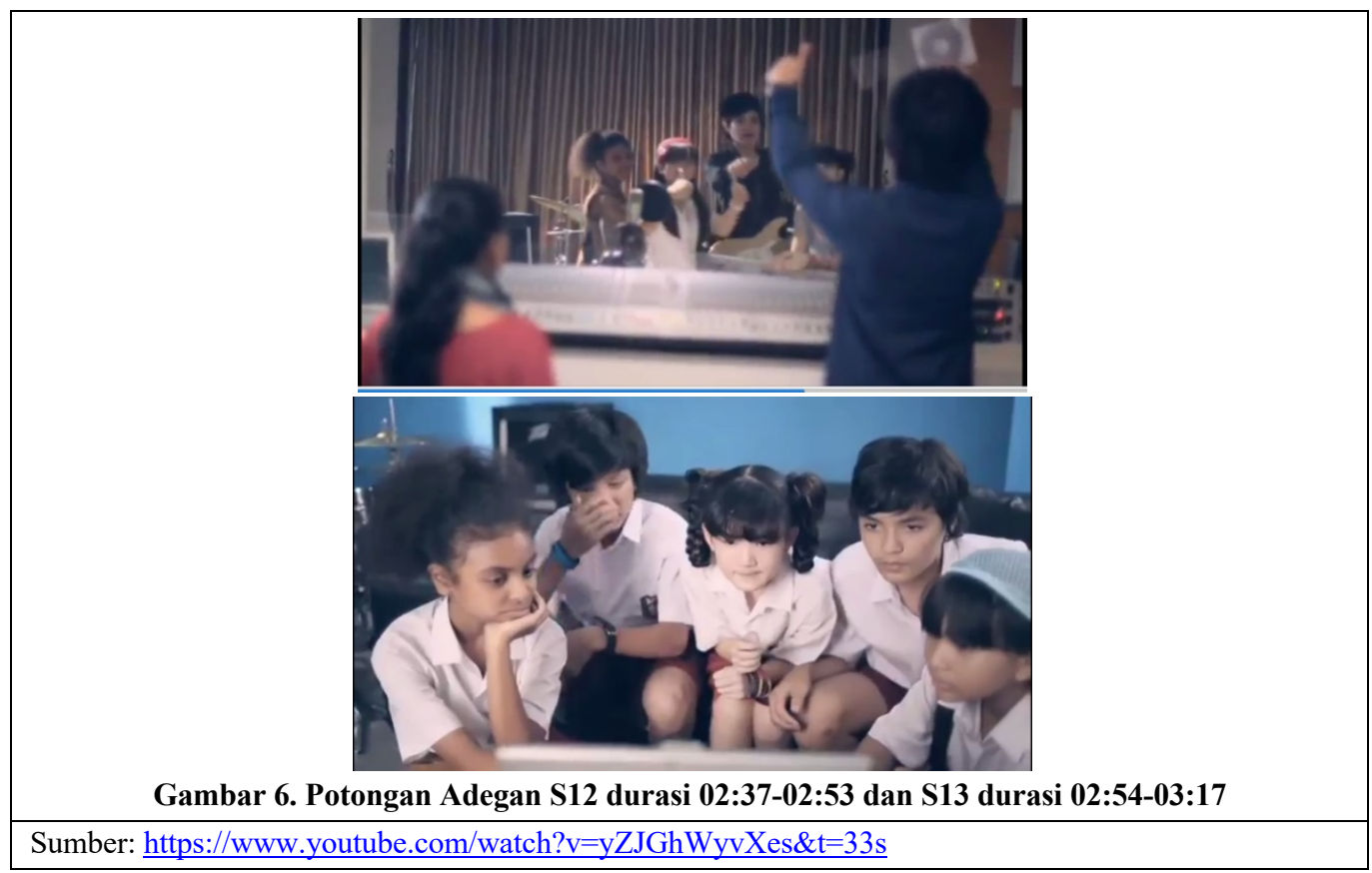

Mengumpulkan uang demi mencapai cita-cita menjadi sebuah band yang nantinya dikenal oleh orang banyak dilakukan dalam beberapa langkah. Setelah memiliki uang yang sudah dikumpulkan secara kolektif, Band Kancil melakukan langkah selanjutnya yaitu pembuatan CD Demo di sebuah studio rekaman. Walaupun berbeda dari scene-scene sebelumnya yang mengedepankan Garasi Rumah Beni ataupun nuansa Kantor BNI, gaya syntagmas tetap terasa dalam paparan akan ikut kompetisi ini. Semua anggota Band Kancil yang sudah menabung berpartisipasi dalam S12 dengan alur chronological. Runut dan teratur, tetapi pemaparan tentang pembuatan CD Demo hanya melalui tataran penggambaran general saja, tidak mendalam, baik dari segi cerita ataupun shot yang digunakan.
Seraya bunyi jam mengiringi "Tik Tok Tik Tok" penantian Band Kancil akan pengumuman Kompetisi Musik. Hasilnya adalah mereka tidak menjadi pemenang, tetapi memiliki ranah dan cara lain untuk tetap menjadi terkenal. Secara susunan cerita, hal ini penting, tetapi secara penggambaran di dalam iklan BNI Taplus Anak, hal ini tidak dikedepankan. Pembuat iklan lebih berfokus pada permainan emosi masingmasing anggota Band Kancil dan khalayak penonton iklan. Mereka menggunakan shot close up, ataupun extreme close up untuk menggambarkan keadaan tegang tersebut. Hal ini diterjemahkan oleh Hanif (2013:93) sebagai bagian dari unsur paradigmatik dalam analisis semiologi film berupa sudut pengambilan gambar, secara garis besar terdapat dua jenis kode, yaitu kode umum dan kode khusus. Kode umum dipahami sebagai kumpulan cara kamera 
mengambil gambar, sementara kode khusus dipandang sebagai ciri khas atau suatu genre, kurun waktu, aliran atau bangsa. Kode khusus berupa makna pluralitas nampak bahwa emosi dimainkan, tetapi ketiadaan shot ini pun tidak akan mengganggu keseluruhan cerita yang sudah dibangun sejak awal. Potongan adegan S13 memiliki pilihan automous shot daripada alur cerita secara mulus untuk keseluruhan cerita.

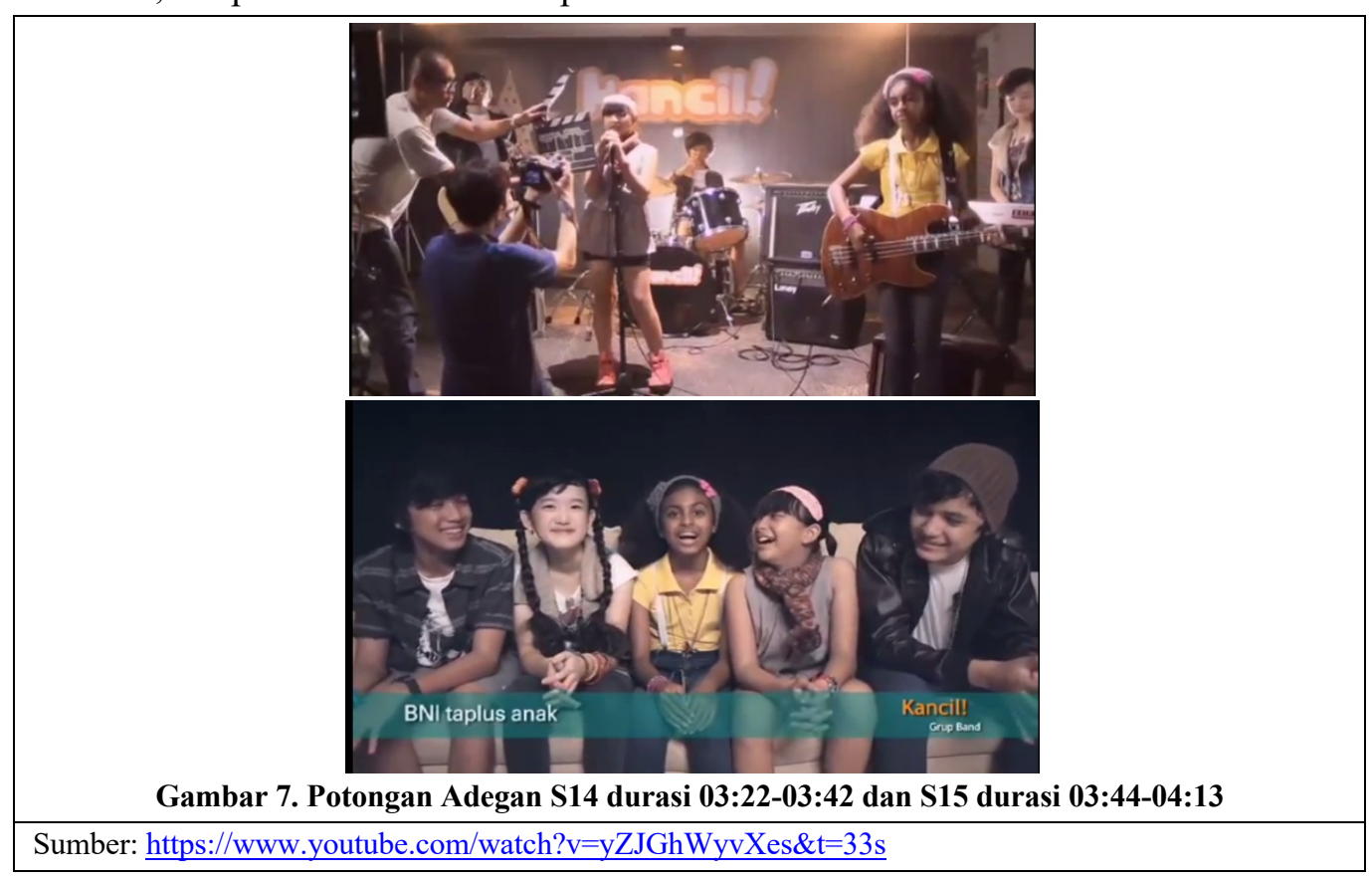

Potongan adegan S14 memiliki ranah yang berbeda dari kompetisi, tetapi tujuan besar untuk dikenal dan membuat sebuah karya yang diakui oleh masyarakat luas tetap diwujudkan. Kegagalan dalam Kompetisi Musik bukan menjadi batu sandungan penghalang dari lima anak yang berasal dari kultur dan suku yang berbeda ini. Mereka tetap kompak membuat karya yaitu video clip dari hasil uang tabungan mereka sendiri. Syntagmas yang dipaparkan adalah impian besar itu tidak padam walau menemui kesulitan. Penyimpangan tujuan jangka pendek yaitu memenangkan kompetisipun terasa (achronological) diiringi dengan alur cerita yang mengalir berdiri sendiri tanpa sejajar dengan paparan yang sudah ada sebelumnya (bracket syntagma).

Jelang akhir iklan BNI Taplus Anak Episode Band Kancil, lima anggota band berkumpul dan menjelaskan terkait mimpi dan capaian yang sudah diraih. Hal ini berlanjut (chronological) dari scene yang sudah dipaparkan sebelumny. Dalam potongan adegan S15 anggota Band Kancil menjelaskan terkait kompetisi yang akhirnya bisa mereka ikuti (walau hasilnya tidak sesuai harapan) dikaitkan dengan semangat menabung. Penguatan gagasan antar anggota Band sangat terasa, sehingga pemaparan narrative terwujud di sini. 
Hal ini semakin kuat manakala kisah mereka dikaitkan dengan kisah sebelumnya (linear narrative) tanpa adanya potongan adegan ke adegan, sehingga sebagai sajian terakhir yang berdiri sendiri cerita tentang pentingnya dan ajakan menabung masuk dalam tataran scene.

Struktur kebahasaan Metz mencerminkan suatu logika sinematik yang menuntun para penonton menyibak pesan tersirat di baliknya. Penelitian ini tidak hanya berhenti pada proses analisis deskriptif dan ketegorisasi secara komprehensif, namun terlebih ingin menguak perjalanan alur cerita yang secara konsisten mengusung asumsi utama peneliti berupa makna pluralitas. Konsekuensi logis manusia atas perbedaan serta keberagaman di sekelilingnya, Nihaya (2014:27) mencatat bahwa pluralitas hadir guna menjawab perbedaan tersebut sebagai pengetahuan yang diterima baik secara pribadi maupun kelompok. Tayangan iklan BNI Taplus Anak yang menghadirkan kisah Band Kancil menyuguhkan suatu plot cerita yang runut, berdasarkan Tabel.2 mengenai rekapitulasi alur cerita iklan nampak setiap bagiannya menyuarakan secara dominan adanya suatu syntagmachronological yang diperoleh dari setiap potongan adegan. Hal ini berarti makna secara tersirat yang menampilkan tatanan pluralitas dibahasakan mengalun ke depan serta memiliki alur sistematis. Sineas yang menciptakan ide kreatif pembuatan iklan ini berhasil merajut jalannya cerita secara kongruen (hanya adegan S09 dan S13 yang tidak mengikuti alur cerita), tidak hanya berpaku pada imaji produk sebagai penyokong nilai produksinya namun tanggung jawab moral dalam menyajikan ide cerita berhasil terpaparkan kepada khalayak penonton.

Tabel 2. Rekapitulasi Alur Kebahasaan Iklan BNI Taplus Anak

\begin{tabular}{|c|c|c|c|c|c|c|c|c|c|c|c|c|c|c|c|}
\hline \multirow{3}{*}{ No. } & \multirow{3}{*}{ Adegan } & \multicolumn{14}{|c|}{$7^{\text {th }}$ Step Metz Grande Syntagmatique } \\
\hline & & \multicolumn{2}{|c|}{1} & \multicolumn{2}{|c|}{2} & \multicolumn{2}{|c|}{3} & \multicolumn{2}{|c|}{4} & \multicolumn{2}{|c|}{5} & \multicolumn{2}{|c|}{6} & \multicolumn{2}{|c|}{7} \\
\hline & & $\mathbf{A}$ & $\mathbf{B}$ & $\mathbf{C}$ & $\mathbf{D}$ & $\mathbf{E}$ & $\mathbf{F}$ & $\mathbf{G}$ & $\mathbf{H}$ & I & $\mathbf{J}$ & $\mathbf{K}$ & $\mathbf{L}$ & & $\mathbf{N}$ \\
\hline S02 & Pengamen akan bernyanyi dan Perkenalan Band Kancil & & & & & & & & & & & & & & \\
\hline S03 & Pengetahuan Band Kancil tentang Kompetisi Musik & & & & & & & & & & & & & & \\
\hline S04 & $\begin{array}{l}\text { Beni melihat dan menghubungkan Kompetisi Musik dengan } \\
\text { BNI Taplus Anak }\end{array}$ & & & & & & & & & & & & & & \\
\hline S07 & $\begin{array}{l}\text { Beni, Mutia dan Betty memegang Buku Tabungan BNI } \\
\text { Taplus Anak }\end{array}$ & & & & & & & & & & & & & & \\
\hline S09 & Keinginan Tommy untuk belanja tetapi ditahan oleh Betty & & & & & & & & & & & & & & \\
\hline $\mathrm{S} 10$ & Tommy bangga dengan Kartu ATM yang dimiliki & & & & & & & & & & & & & & \\
\hline $\mathrm{S} 11$ & $\begin{array}{l}\text { Anggota Band Kancil menarik uang dari ATM dan } \\
\text { mengumpulkan uang hasil tabungan }\end{array}$ & & & & & & & & & & & & & & \\
\hline S12 & Pembuatan CD demo rekaman Band Kancil & & & & & & & & & & & & & & \\
\hline
\end{tabular}




\begin{tabular}{|c|l|l|l|l|l|l|l|l|l|l|l|l|l|}
\hline S13 & $\begin{array}{l}\text { Menunggu waktu pengumuman dan hasil pengumuman } \\
\text { Kompetisi Musik }\end{array}$ & & & & & & & & & & & \\
\hline S14 & Pembuatan Video Clip Band Kancil & & & & & & & & & & & & \\
\hline S15 & $\begin{array}{l}\text { Ajakan Band Kancil kepada khalayak tujuan untuk } \\
\text { menabung }\end{array}$ & & & & & & & & & & \\
\hline
\end{tabular}

Keterangan: (A) Autonomous Shot; (B) Syntagmas; (C) Achronological; (D) Chronological; (E) Parallel Syntagma; $\quad$ (F) Bracket Syntagma; $(G)$ Descriptive Syntagma; (H) Narrative; (I) Alternate (Narrative Syntagma); (J) Linear Narrative; (K) Scene; (L) Sequences; (M) Episodic;(N) Ordinary. (Sumber: Olahan Peneliti)

Pluralitas tidak hanya terpatri di tataran permukaan atau deskriptif saja, melainkan muncul secara narativelinear. Dimaksudkan bahwa pola bercerita secara kronologis ditelusuri pada tingkatan yang lebih kecil lingkup kerangkanya menyiratkan makna tersirat yang serupa berupa pluralitas. Tokohtokoh yang berperan hingga perilaku yang secara unsur sinematik ditelusuri berhasil memberi gambaran berupa konsistensi pluralitas sejak dari upaya meraih impiannya untuk memenangkan kompetisi musik (adegan S03 dan S04) hingga jerih payah menyisihkan uang untuk ditabung (adegan S10, S11, S15). Hal serupa masih dipertahankan sineas iklan BNI Taplus Anak ini pada kelompok-kelompok adegan yang memiliki keberlanjutan cerita atau sequences-episodic. Terbukti pada adegan S04 yang masih menceritakan usaha Band Kancil berlatih guna meraih impiannya, kemudian disusul dengan tambahan adegan S11 berupa antusias kelima anggota band tersebut memberdayakan tabungan BNI sebagai sarana menghimpun sumber daya materiil guna mendaftar kompetisi musik.

\section{SIMPULAN}

Proposisi Metz mengungkapkan bahwa film dapat diamati seakan-akan memiliki kedudukan struktural serupa bahasa, dimana suatu teks sinematik diperluas untuk menemukan kategori-kategori yang dibuat oleh bahasa dengan menggabungkan unsur dialog, musik, adegan, dan peran dalam suatu cara yang kohesif. Unsur sinematik film serupa dengan iklan komersial televisi, tidak jarang padanan alur cerita disajikan dalam dramatisme yang mampu membuai khalayak penontonnya.

Temuan riset dari semiologi pada Iklan BNI Taplus Anak diperoleh bahwa makna secara tersirat yang menampilkan tatanan pluralitas dibahasakan mengalun ke depan serta memiliki alur sistematis tidak hanya berpaku pada imaji produk sebagai penyokong nilai produksinya namun tanggung jawab moral dalam menyajikan ide cerita berhasil terpaparkan kepada khalayak penonton. Hal ini senada dengan analisis Hernawan (2018:6) yang menyatakan bahwa pengembangan inspirasi dan ide kreatif dalam bentuk 
film diwujudkan dalam dua unsur, yaitu naratif dan sinematik. Keduanya dirangkai sedemikian rupa oleh sineas yang terdiri dari sutradara, juru kamera, dan penyunting atau editor. Demikian pula sineas yang menciptakan ide kreatif pembuatan iklan BNI Taplus Anak ini berhasil merajut jalannya cerita secara kongruen, pola bercerita secara kronologis ditelusuri pada tingkatan yang lebih kecil lingkup kerangkanya menyiratkan makna yang serupa dan konsisten berupa pluralitas.

Bagi para akademisi diharapkan penelitian ini dapat diekstensifikasi pada tataran yang lebih kompleks cakupannya dengan bantuan kerangka metodologis serta intervensi dari perspektif multi disiplin ilmu melalui pemahaman teoritis yang lebih luas bahasannya. Kontribusi penelitian ini juga diarahkan bagi para praktisi periklanan maupun perfilman, agar senantiasa mempertimbangkan alur kebahasaan sinematik sebagai sarana peningkatan konsistensi produksi tayangan iklan maupun film yang memiliki unsur sinemanya. Selain itu, bagi komunitas tertentu baik yang berhubungan dengan produk perbankan maupun musisi muda berbakat dalam upayanya menggapai impian mereka, semoga semangat pencapaiannya dapat terinspirasi melalui pemaknaan yang berhasil ditemukan riset ini. Selanjutnya, mampu membuka wawasan masyarakat pada umumnya terkait pemahaman akan pluralitas pada unsur sinematik iklan sebagai pemantik pemahaman multikulturalisme.

\section{DAFTAR PUSTAKA}

Sumber Literatur:

Achmad. 2014. 'Pluralisme dalam Problema' dalam Jurnal Sosial Humaniora (JSH) Vol.7(2) PP. 189-204

Astra, I Gde Semadi. 2014. 'Pluralitas dan Heterogenitas dalam Konteks Pembinaan Kesatuan Bangsa' dalam Jurnal Kajian Budaya Vol.10(20) PP.1-20

Batemen, A. John. 2012. Multimodal Film Analysis : How Film Mean. London: Routledge.

Bellour, Raymond. 2000. The Analysis of Film. Bloomington: Indiana University Press.

Biyanto. 2015. 'Berdamai dengan Pluralitas Paham Keberagaman' dalam Jurnal Teosofi: Tasawuf dan Pemikiran Islam Vol.5(1) PP. 164-189

Collins, James T. 2014. 'Keragaman Bahasa dan Kesepakatan Masyarakat: Pluralitas dan Komunikasi' dalam Jurnal Dialektika Vol.1(2) PP.149-180

Dewi, Alga Lilis, Muhammad Zamroni, Soekma Yeni Astuti. 2017. 'Analisis Semiotika Film Christian Metz: Studi Kasus Visualisasi Pesan Religi dalam Film Hijrah Cinta' dalam 
Jurnal Publika Budaya Vol.5(1)

PP.21-27

Faisal, Akhmad Riza. 2009. 'Cult

Film dan Analisa Semiotika

Film pada Nagabonar Jadi 2'

dalam Jurnal Ilmu Komunikasi

Vol.6(1) PP.1-118

Hanif, Wildan. 2013. 'Analisis

Semiotika Film Iran Karya

Majid Majidi: Children of

Heaven, Color of Paradise, dan

Baran' dalam Atrat: Visual Art

and Design Journal Vol.1(1)

PP.90-108

Hanitzch, Thomas. 2001. Teori

Sistem Sosial dan Paradigma

Konstruktivisme: Tantangan

Keilmuan Jurnalistik di Era

Informasi dalam Jurnal

Mediator Vol.2(2) PP.217-229

Hasbullah. 2012. 'Konflik Sosial

Bernuansa Religius' dalam

Jurnal Ushuluddin Vol.18(1)

PP.34-48

Hawasi, 2005. 'Aktualisasi

Paradigma Multikulturalisme dalam Budaya Indonesia yang Plural dalam Proceeding Seminar Nasional PESAT 2005

di Auditorium Universitas Gunadarma tanggal 23024 Agustus 2005

Hernawan. 2018. 'Dari Inspirasi hingga Apresiasi' dalam Jurnal Layar Vol.5(2) PP.3-17

Hernawan, Wawan. 2017. 'Prasangka

Sosial dalam Pluralitas

Keberagaman di Kecamatan

Cigugur Kabupaten Kuningan

Jawa Barat' dalam Jurnal
Sosiohumaniora

Vol.19(1)

PP.77-85

Heywood, Andrew. 2007. Political

Ideologies (4th Edition).

Palgrave: McMillan

Krisna, Wijayanti. 2016. 'Makna Pesan pada Film Action (Analisa Semiotik pada Film Action yang Mencapai Box Office Tahun 2015)' dalam SEMIOTIKA: Jurnal Komunikasi Vol.10(1) PP.207240

Lail, Jamalul, Ari Maulana. 2015. 'Program Sentono Menabung' dalam Jurnal Inovasi dan Kewirausahaan Vol.4(1) PP.54-57

Metz, Christian. 1982. The Imaginary Signifier: Psychoanalysis and the Cinema. Bloomington: Indiana University Press

Metz, Christian. 1990. Film Languange: A Semiotics of the Cinema. Chicago: University of Chicago Press

Natalia, Priccila, Mumuh Mulyana. 2014. 'Pengaruh Periklanan dan Promosi Penjualan terhadap Keputusan Pembelian' dalam Jurnal Ilmiah Manajemen Kesatuan (JIMKES) STIK Kesatuan Vol.2(2) PP.119-128 Nihaya. 2014. 'Pandangan Masyarakat terhadap Pluralisme dan Radikalisme di Makassar' dalam Jurnal Sulesana Vol.9(2) PP.18-32

Ropii, Imam. 2017. 'Penghormatan Pluralitas Hukum Masyarakat 
dalam Bingkai Hukum

Nasional sebagai Sarana

Meneguhkan Integrasi Bangsa'

dalam Jurnal Prasada Vol.4(1)

PP.12-21

Sapendi. 2012. 'Pendidikan

Pluralisme Agama

(Membangun Hubungan Sosial

Lintas Agama di Sekolah)'

dalam Jurnal Khatulistiwa:

Journal of Islamic Studies

Vol.2(2) PP.154-172

Supano, Lilik. 'Nilai-Nilai Pluralisme dalam Mata Pelajaran Sejarang Kebudayaan Islam (Studi Analisis Isi terhadap Buku Ajar SKI MA' dalam Jurnal Pendidikan Agama Islam Vol.VI(1) PP.71-85

Syam, Firdaus. 2011. 'Dilema Pluralitas: Hambatan atau Penguatan Demokrasi Bangsa Indonesia' dalam Jurnal Ilmu Hukum Vol.14(2) PP.256-275

Ulfi, Dina Shofa, Siswandari, Dini Octoria. 2017. 'Hubungan
Literasi Keungan dan Perilaku

Teman Sebaya dengan

Kebiasaan Menabung' dalam

Jurnal Tata Arta Universitas

Negeri Sebelas Maret Vol.3(1)

PP.12-21

Yuniyanto, Herdian Rizky, Hani Sirine. 2018. 'Pengaruh Iklan terhadap Minat Beli Pengguna Youtube dengan Brand Recognition sebagai Variable Intervening' dalam Esensi: Jurnal Bisnis dan Manajemen Vol.8(1) PP.21-28

Sumber Daring:

https://www.youtube.com/watch?v= yZJGhWyvXes

https://swa.co.id/swa/listed-

articles/ingin-garap-nasabah-

lifetime-bni-taplus-anak-diluncurkan http://www.bni.co.id/id-

$\mathrm{id} /$ personal/simpanan/bnitaplusanak http://www.kongresbud.budpar.go.id 158\%20ayyumardi\%20azra.htm 